\title{
(Im)moral aspects of attitudes towards immigrants: The role of the Dark Tetrad and Moral Foundations
}

\author{
Boban Petrović* \\ Institute of criminological and sociological research, Belgrade
}

Immigration and refugee crisis are only one of the major problems many European countries are currently facing, including the transition countries, such as Serbia. Reactions to refugees and immigrants from the Middle East and North Africa are polarized and raise the issue of moral aspects of attitudes towards them. Lately, human (im)morality has often been investigated through the concepts of the Dark Tetrad traits and Moral Foundations. The aim of this research aim is to investigate the role of the Dark Tetrad traits and Moral Foundations in the understanding of general and specific, situation-related prosocial attitudes towards immigrants. The results of the current study ( $\mathrm{N}=629$ respondents from Serbia) have shown that Harm/ Care and Fairness/Reciprocity (Individualizing Foundations) correlated negatively with the Dark Tetrad traits. On the other hand, Ingroup/Loyalty, Authority/Respect and Purity/Sanctity (Binding Foundations) correlated positively with these traits. The general attitude towards immigrants is mainly explained by moral foundations: the positive effect of Harm/Care and negative effects of Authority/Respect and Purity/Sanctity were detected, with the marginal negative effect of Machiavellianism. The specific attitude towards immigrants is explained both by the Dark Tetrad traits and Moral Foundations. The expected positive effect of Fairness/Reciprocity and negative effects of sadism and Purity/Sanctity were also registered. Moral Foundations mediate the relationships between the Dark Tetrad traits and both the general and specific attitudes towards immigrants. Only narcissism and sadism have direct effects on attitudes towards them. The Binding Foundations amplified, while the Individual Foundations diminished the negative effects of the Dark Tetrad traits on both the general and specific attitudes towards immigrants. These results suggest that when people perceive threats from the "others" to their inner circle, formal boundaries of morality are weakened and even most malicious personality traits are expressed.

Key words: morality, immigrants, attitudes, Dark Tetrad, Moral Foundations

* deceased 


\section{Introduction}

Immigration and refugee crisis are currently one of the major problems for many European countries, including the so-called transition countries, such as Serbia. It maybe argued that the current massive influx of refugees into the EU poses challenges for solidarity and responsibility for both the states and individuals (Veebel \& Markus, 2015). One of the biggest concerns includes the polarized reactions of the citizens of European countries, including Serbia as one of the key countries on the Western-Balkan Route of refugees and immigrants from Syria, Iraq, Afghanistan and North Africa. Namely, some individuals advocate solidarity and provide support to immigrants, but others seem to be against it and endorse rigorous policies and violence towards them (Ceobanu \& Escandell, 2010; Denda, 2014; Petrović, 2018).

Such polarized attitudes reflect different morally-relevant motives of their exponents: to help the people in need or to defend their own country and ingroup from the immigrant threat. The primary reason for that was postulated within the integrated threat theory (Stephan et al., 1998), proposing that the reactions of domiciles towards the people from different cultures are caused by the perception of a realistic (i.e., threats to physical safety, health, economic and political power, threats to the existence of the group) and symbolic (the feeling of threat to the cultural and social identity) threat from an outgroup. Thereby, some previous research has shown that immigration is rather perceived as a threat than as a benefit (Meltzer et al., 2018). Secondly, the experience of threats to cultural norms and identity leads to much more adverse attitudes towards immigrants than a threat to economic interests (Hainmueller \& Hopkins, 2014). A recent study has shown that besides economic factors, the cultural ones, such as skin tone and especially religious affiliation, significantly decrease immigration support (Valentino et al., 2017). Thus, it could be said that both antagonistic and prosocial, supportive attitudes towards immigrants lead to the question of morality and moral roots of attitudes towards them (see e.g., Nicol \& Rounding, 2017), as well as raise the question of conditions that promote these attitudes.

\section{Two sides of human (im)morality: The Dark Tetrad personality traits and} Moral Foundations

During the last decade, human (im)morality has often been investigated through the concepts of the dark traits and moral foundations. The first includes personality dispositions towards immoral, deceitful and antisocial behaviour: Machiavellianism (manipulation and cynicism), narcissism (a sense of grandiosity and entitlement), psychopathy (callousness, impulsivity, and lack of remorse) and sadism (the tendency of intentionally hurting others or watching others in pain). The first three are commonly known as the Dark Triad (Paulhus \& Williams, 2002), but there is growing empirical evidence 
that sadism could be added to these three and that the Dark Triad could be extended into the Dark Tetrad (Chabrol, Van Leeuwen, Rodgers, \& Séjourné, 2009; Buckels, Jones, \& Paulhus, 2013; Međedović \& Petrović, 2015).

The Moral Foundations aret he most recent model of human morality (Haidt \& Graham, 2007; Graham et al., 2011). This model argues that human morality can be described by five moral domains or foundations. Harm/Care (preventing harm to others) and Fairness/Reciprocity (preserving fairness, equal rights, and justice) constitute Individualizing moral foundations, which are primarily concerned with protecting rights and freedoms of individual people. Ingroup/Loyalty (practicing loyalty towards one's ingroup), Authority/ Respect (respecting tradition and authority within hierarchical relationships) and Purity/Sanctity (practicing purity or sanctity of the body, mind, and soul), which represent the so-called Binding foundations, are focused on preserving the group as a whole (Graham et al., 2013; Haidt \& Graham, 2007).

Although it would be expected that the Dark Tetrad traits and all five Moral Foundations are negatively related (under the assumption that all five reflect moral concerns), recent empirical findings show that Individualizing moral foundations are systematically negatively related, while the Binding foundations are mainly not related with the Dark Tetrad traits (Karandikar, Kapoor, Fernandes, \& Jonason, 2018; Međedović \& Petrović, 2016).

Both of these sets of dispositions are undoubtedly important for understanding human (im)morality. Therefore, they are also important for understanding a broad range of human social and political behaviours. Thus, Individualizing moral foundations are positively related with liberal political ideology and negatively with Social Dominance Orientation - SDO (Kugler, Jost \& Noorbaloochi, 2014). However, both the Binding moral foundations and Dark Tetrad traits are positively related with conservative political ideology, RWA and SDO (Duspara \& Greitemeyer, 2017; Hodson, Hogg, \& MacInnis, 2009; Jones, 2013; Kugler et al., 2014; Milojev et al., 2014). Additionally, these ideological orientations, but also the Dark Tetrad traits and Moral Foundations themselves, are associated with asocial or even antisocial outcomes like racism and Neo-Nazi support (Jonason, 2015; Jones, 2013), prejudices (Hodson et al., 2009), outgroup hostility (Hadarics \& Kende, 2018; Kugleret al., 2014), etc. This is why some scholars claim that Binding moral foundations are rather amoral or immoral than moral aspects of human functioning (Kugler et al., 2014).

\section{(Im)moral aspects of attitudes toward immigrants: Recent findings}

There have only been a few studies so far that investigated the relations between the dark personality traits and prejudices and attitudes towards immigrants that clearly supported the prominent role of dark personality traits. For instance, Hodson and colleagues were among the first who showed 
that all three Dark Triad traits correlated positively with the outgroup threat perceptions and anti-immigrant prejudice, as well as that outgroup threat perceptions mediate the relations between the dark traits and anti-immigrant prejudice (Hodson et al., 2009). Anderson and Cheers (2018) showed that all three Dark Triad traits were associated with the negative attitudes towards asylum seekers but that Machiavellianism had an important role in the understanding of classic (more overt) prejudices, while psychopathy significantly predicted modern (more subtle) prejudices toward asylum seekers. Međedović and Bulut (2017) found that all four Dark Tetrad traits were associated with the perceptions of both the realistic and symbolic threat of immigrants, except narcissism, which was unrelated with the perception of a realistic threat. Additionally, psychopathy predicted the perception of a realistic threat, but the perception of a symbolic threat was predicted by narcissism. Međedović and Bulut concluded that attitudes towards immigrants are rather correlates than a specific form of expression of the Dark Tetrad traits, but that the Dark Tetrad could be the basis for negative attitudes toward immigrants, whose relation is probably mediated by some ideological dispositions.

When it comes to Moral Foundations and their relations with prejudices and attitudes towards immigrants, Kugler and colleagues (Kugler et al., 2014) found that Individualizing moral concerns, especially Fairness/Reciprocity, had negative effects, but all three Binding moral concerns had positive effects on intergroup hostility and support for discrimination against foreigners and immigrants. Similarly, Binding moral foundations (especially Purity/Sanctity and Authority/Respect) were positively associated with anti-immigrant attitudes (Koleva et al., 2012); however, the Individualizing ones were negatively associated with the perceived threat regarding immigration, both realistic and symbolic (Hadarics \& Kende, 2017), and a negative behavioural intention towards the Muslim people, especially immigrants (Hadarics \& Kende, 2018).

\section{Goals of the present study}

The main aim of this research is to investigate the contribution of morally-relevant personality traits (the Dark Tetrad traits) and beliefs (Moral Foundations) in the prediction of general as well as situation-related prosocial attitudes towards immigrants. The measurement of these two types of attitudes has the intention to facilitate the feeling of threat by immigrants. The general attitude towards immigrants was measured by the item which did not contain any specific information about immigrants that could put them in any value context. Contrary to that, the specific attitude towards immigrants was measured by an item that contained explicit information 
about the characteristics of immigrants, the countries of their origin and the reasons for their arrival in the host country (Serbia, in this case). This item should more effectively facilitate the feeling of threat and activate the processes relevant to moral behaviour.

We speculated that the dark traits (especially Machiavellianism and psychopathy, probably sadism) will negatively contribute to the explanation of the attitudes towards immigrants, but that the Individualizing moral foundations (primarily Fairness/Reciprocity) will have a positive contribution. However, in the case of the Binding foundations, there are more difficulties with making a clear hypothesis. We postulated two alternative hypotheses. Starting from the basic assumption of the Moral Foundations Theory (that both the Individualizing and Binding moral intuitions reflect human morality, although the Binding ones are not recognized as moral by liberals (Haidt \& Graham, 2007)), positive associations between the Binding foundations and prosocial attitudes towards immigrants could be expected. However, having in mind the study of Kugler and colleagues (2014), the expected contributions of the Binding foundations could be negative. We expect the strongest effect of Purity/Sanctity, followed by Authority/Respect. We also propose that the dark personality traits, as more fundamental moral dispositions, will have a more important role in the prediction of a situation-related attitude towards immigrants, which provoke the feeling of threat more directly. Finally, it should be kept in mind that attitudes, values and beliefs mediate the effects of personality traits on prejudices (Sibley et al., 2010), but also that Moral Foundations are important mediators of, for example, relations of the dark personality traits with moral judgments (Djeriouat \& Trémolière, 2014), or RWA and SDO with the perceived threat to immigration (Hadarics \& Kende, 2017). In line with these, we also speculate that Moral Foundations will mediate the relations between the dark traits and both the general and specific attitudes towards immigrants. More specifically, we hypothesize that the Binding foundations will amplify, while Individualizing foundations will diminish the negative effects of the Dark Tetrad traits on both the general and specific attitudes towards immigrants.

\section{Method}

\section{Sample and procedure}

There were 629 respondents from the general population of Serbian citizens in this study. Majority of them (95.8\%) were of Serbian nationality. The average age of the participants was 25.10 years $(\mathrm{SD}=7.74$; ranged from 17 to 68 years), with $25.3 \%$ of male participants. Average education was 14.88 years of formal education $(\mathrm{SD}=2.19)$. Data were collected via an online study. 
The web page for data collection was created specifically for the realization of this study (socstav.tangoheat.com). Participants were motivated to participate by a possibility to receive feedback regarding their results on the administrated questionnaires, an opportunity which most of them used. The informed consent was included on the first page of the questionnaire.

\section{Measures}

Prosocial attitudes towards immigrants. General and specific, situationrelated attitudes towards immigrants were measured. The general attitude was operationalized through the item "Foreigners and immigrants have a beneficial effect on our society" $(\mathrm{M}=3.27, \mathrm{SD}=1.03)$. Respondents rated the item on a five-point scale $(1=$ strongly disagree, 5 = strongly agree $)$. The specific, situation-focused attitude towards immigrants was measured through the item "In your opinion, to what extent should Serbia allow the people from other countries, regardless of their skin colour, nationality or country of origin, to immigrate, live and work in Serbia?" $(\mathrm{M}=4.28, \mathrm{SD}=.96)$. Participants rated the item on a five-point scale $(1=$ Do not allow anyone, $5=$ Allow all who want to come, live and work here). The coefficient of correlation between these two items was $.32(\mathrm{p}<.001)$.

Dark Triad traits. The Short-Dark Triad (Jones \& Paulhus, 2014) describes a brief 27-item measure of Machiavellianism, psychopathy, and narcissism, all of which have nine-item scales. Cronbach's a coefficients of reliability are .78, .74 and .70 , for each of these measures respectively.

Sadism. Sadism was assessed via the Short Sadistic Impulse Scale (SSIS; O'Meara, Davis, \& Hammond, 2011), which consists of 10 items intended to measure the tendency to enjoy hurting others $(\alpha=.85)$.

Moral Foundations. Moral foundations were assessed using the 30item Moral Foundations Questionnaire (MFQ; Graham et al., 2011). This scale consists of two parts, each containing 15 items. Each of five moral foundations (Harm/Care, Fairness/Reciprocity, Ingroup/Loyalty, Authority/ Respect and Purity/Sanctity) were assessed using self-report items that asked the participants to (1) evaluate the extent to which each statement is "relevant to their thinking" when making decisions about right and wrong (e.g. "Whether or not someone was cruel") and (2) indicate their agreement or disagreement with normative declarations such as "One of the worst things a person could do is hurt a defenceless animal." The responses in these two sections have been shown to be positively correlated (Graham et al., 2011) and thus were analysed in combination, yielding six items per foundation. All five subscales showed good reliabilities $(.69, .76, .72, .76$ and .72 for each of the subscales, respectively). 
All questionnaires had a joint five-point Likert-type scale, from 1-strongly disagree to 5 - strongly agree, except the MFQ where the participants rated the items on a six-point scale ( $0=$ strongly disagree; $5=$ strongly agree $)$. All of the scales used in the research were previously administered in Serbia, and their good psychometric characteristics and validity were already demonstrated (Dinić, Petrović, \& Jonason, 2018; Dinić et al., under review; Međedović \& Petrović, 2016).

\section{Results}

Descriptive statistics and correlations between the examined variables

As can be seen from Table 1, correlations between the Dark Tetrad traits range from positive and small to moderate in strength. The correlations of psychopathy with Machiavellianism and Sadism are moderate, but associations of all of these three traits with narcissism are small in effect. In the case of the Moral Foundations, Harm/Care and Fairness/Reciprocity, but also Ingroup/ Loyalty, Authority/Respect and Purity/Sanctity correlated positively and highly. However, associations between Harm/Care and Fairness/Reciprocity with the other three Moral Foundations were neither significant nor weak.

Table 1

Descriptive statistics and correlations (Under the Bonferroni corrections)

\begin{tabular}{|c|c|c|c|c|c|c|c|c|c|c|c|}
\hline & \multirow{2}{*}{ M } & \multirow{2}{*}{ SD } & \multicolumn{9}{|c|}{ Correlations } \\
\hline & & & 1 & 2 & 3 & 4 & 5 & 6 & 7 & 8 & 9 \\
\hline 1 Machiavellianism & 2.82 & .70 & 1 & & & & & & & & \\
\hline 2 Narcissism & 2.85 & .63 & $.32^{* *}$ & 1 & & & & & & & \\
\hline 3 Psychopathy & 1.98 & .65 & $.53^{\star \star}$ & $.39^{* *}$ & 1 & & & & & & \\
\hline 4 Sadism & 1.63 & .52 & $.30^{\star *}$ & $.23^{\star *}$ & $.62^{\star *}$ & 1 & & & & & \\
\hline 5Harm/Care & 3.85 & .74 & $-.18^{\star *}$ & -.07 & $-.33^{* *}$ & $-.42^{* *}$ & 1 & & & & \\
\hline 6 Fairness/Reciprocity & 3.82 & .69 & $-.12^{\star *}$ & -.02 & $-.27^{\star \star}$ & $-.37^{* *}$ & $.65^{\star *}$ & 1 & & & \\
\hline 7 Ingroup/Loyalty & 3.00 & .90 & $.17^{\star *}$ & .10 & .03 & $-.12^{* *}$ & $.27^{\star *}$ & $.19^{* *}$ & 1 & & \\
\hline 8 Authority/Respect & 2.55 & .95 & $.26^{* *}$ & $.15^{\star \star}$ & .10 & .02 & .10 & -.01 & $.74^{\star *}$ & 1 & \\
\hline 9 Purity/Sanctity & 2.79 & .94 & .09 & .10 & -.08 & -.09 & $.27^{\star *}$ & $.18^{\star *}$ & $.66^{\star *}$ & $.68^{\star \star}$ & 1 \\
\hline
\end{tabular}

Notes: ${ }^{\star}-\mathrm{p}<.05 ;{ }^{\star \star}-\mathrm{p}<.01$, significant with Bonferroni correction

Bivariate correlations between the Dark Tetrad traits and five Moral Foundations are very interesting. Namely, both Harm/Care and Fairness/ Reciprocity have negative, low to moderate correlations with all the Dark Tetrad traits except narcissism. However, correlations between the other three Moral Foundations and the Dark Tetrad traits are neither significant nor positive and low in magnitude. Only Machiavellianism was systematically positively correlated with Authority/Respect and Ingroup/Loyalty. 


\section{The Dark Tetrad and Moral Foundations as predictors of the attitudes towards immigrants}

Hierarchical regression analysis was performed with the aim of examining the specific contribution of the dark traits and moral concerns to understanding both the general and situation-related attitudes towards immigrants. The results are shown in Table 2. In both cases, the above-mentioned set of predictors explained a similar percent of the criteria's variance (21\%, i.e., $18 \%$, respectively). General prosocial attitude towards immigrants is predicted dominantly (16\%) by the Moral Foundations - Harm/Care contributed positively, while Authority/Respect and Purity/Sanctity contributed negatively to the prediction of the general attitude towards immigrants. A marginal negative effect of Machiavellianism was also detected.

Table 2

The Dark Tetrad Traits and Moral Foundations as predictors of the attitudes towards immigrants

\begin{tabular}{lcccccccc}
\hline & \multicolumn{3}{c}{$\begin{array}{c}\text { General attitude } \\
\text { towards immigrants }\end{array}$} & \multicolumn{4}{c}{$\begin{array}{c}\text { Situation-related attitude } \\
\text { towards immigrants }\end{array}$} \\
\cline { 2 - 9 } Gender & $\beta_{1}$ & $\beta_{2}$ & $\beta_{3}$ & $\mathrm{r}_{0}$ & $\beta_{1}$ & $\beta_{2}$ & $\beta_{3}$ & $\mathrm{r}_{0}$ \\
\cline { 2 - 9 } Age & .02 & -.01 & -.03 & .02 & $.09^{*}$ & .03 & .03 & .09 \\
Education & .08 & .07 & .05 & .14 & .08 & .05 & .05 & .09 \\
Machiavellianism & $.13^{* *}$ & $.12^{*}$ & .04 & $.17^{*}$ & .02 & .01 & -.07 & .06 \\
Narcissism & & $-.13^{*}$ & -.02 & $-.14^{*}$ & & -.03 & .02 & $-.14^{*}$ \\
Psychopathy & & .06 & .10 & .01 & & -.04 & -.02 & -.12 \\
Sadism & & -.01 & -.05 & -.09 & & -.03 & -.07 & $-.22^{* *}$ \\
Harm/Care & & -.03 & .03 & -.08 & & $-.21^{* *}$ & $-.18^{* *}$ & $-.26^{* *}$ \\
Fairness/Reciprocity & & & $.23^{* *}$ & $.16^{*}$ & & & .07 & $.15^{*}$ \\
Ingroup/Loyalty & & & .01 & $.14^{*}$ & & & $.12^{*}$ & $.18^{* *}$ \\
Authority/Respect & & & -.01 & $-.26^{* *}$ & & & -.06 & $-.18^{* *}$ \\
Purity/Sanctity & & & $-.26^{* *}$ & $-.37^{* *}$ & & & -.01 & $-.23^{* *}$ \\
\hline $\mathrm{R}^{2}$ & $.03^{*}$ & $.05^{* *}$ & $.21^{* *}$ & & $.02^{*}$ & $.08^{* *}$ & $.18^{* *}$ & \\
$\Delta \mathrm{R}^{2}$ & & $.02^{*}$ & $.16^{* *}$ & & & $.06^{* *}$ & $.10^{* *}$ & \\
\hline
\end{tabular}

Notes: $\beta_{1-3}-$ standardized regression coefficients; $r_{0}$ - zero-order correlation; $R^{2}-$ percent of explained variance; $\Delta \mathrm{R}^{2}$ - change in percents of explained variance through steps; ${ }^{*}-\mathrm{p}$ $<.05 ;{ }^{* *}-\mathrm{p}<.01$.

The situation-related pro-immigrant attitude is predicted both by dark traits $(6 \%)$ and moral concerns $(10 \%)$. All dark traits except narcissism weakly correlate with the situation-related attitude towards immigrants, and only sadism stands out as a significant predictor. Similarly, as in the case of the general attitude towards immigrants, Harm/Care and Fairness/Reciprocity are positively correlated, while Ingroup/Loyalty, Authority/Respect and 
Purity/Sanctity are negatively correlated with the situation-related attitude towards immigrants. However, only Purity/Sanctity (negatively) and Fairness/ Reciprocity (positively) contribute to the prediction of the situation-related attitude towards immigrants.

\section{Moral Foundations as mediators between the dark personality traits and attitudes towards immigrants}

The hypothesis that moral concerns mediate the relationships between the Dark Tetrad traits (set as exogenous variables in the model) and both the general and situation-related attitudes towards immigrants (set as endogenous variables) was also tested. However, before the setting of the path model, the five Moral Foundations were factor-analysed (under the Maximum Likelihood conditions; the extracted factors were rotated in Promax position), with the aim to reduce the number of variables to be included in the model as mediators. Following the theoretical expectations, two factors were extracted (see Figure A1 in the Appendix). The first one $\left(\lambda_{1}=2.58,51.5 \%\right.$ of the variance) captured the Ingroup/Loyalty, Authority/Respect and Purity/Sanctity. It was interpreted as the Binding Moral Foundations. The second one $\left(\lambda_{2}=1.50\right.$, $30.0 \%$ of the variance) consisted of the Harm/Care and Fairness/Reciprocity, and it was labelled as the Individualizing Moral Foundations. These two second-order variables were entered in the path model as mediator variables. The model, displayed in Figure 1, showed adequate fit indices $\left(\chi^{2}=5.42, \mathrm{df}=8\right.$, $\mathrm{p}>.01 ; \mathrm{CMIN} / \mathrm{df}=.68$; NFI=.99; CFI=.99; RMSEA=.00).

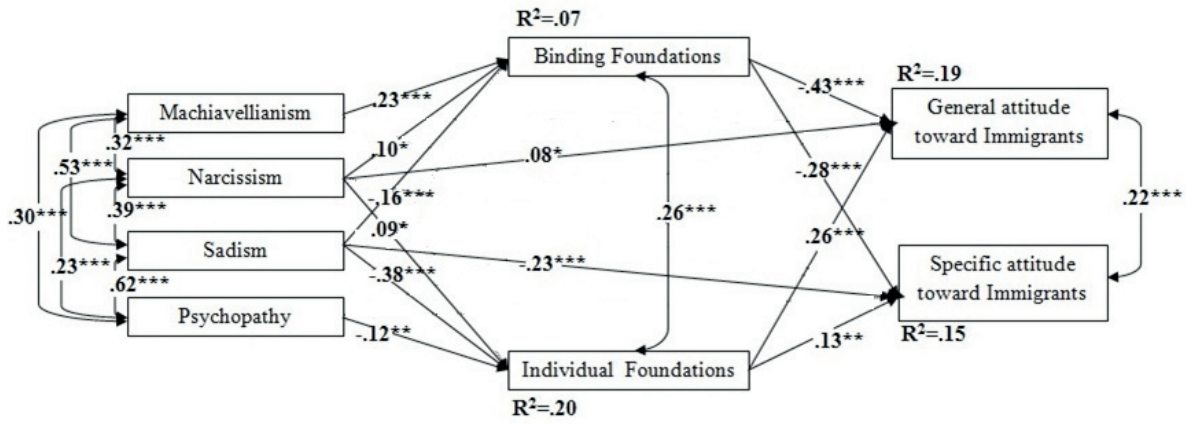

Figure 1. Moral Foundations as partial mediators of the relations between the Dark Tetrad traits and attitudes towards immigrants. Only significant paths are depicted with solid lines. Figure values are standardized regression coefficients. ${ }^{*}-\mathrm{p}<.05 ;{ }^{* *}-\mathrm{p}<.01{ }^{* *}-\mathrm{p}<.001$

As can be seen, the Binding moral concerns have negative and weak to moderate pathways towards both pro-immigrants attitudes. However, the 
Individualizing ones have weak positive pathways towards both general and specific attitudes. Narcissism has a weak positive direct effect on the general prosocial attitude towards immigrants, but sadism has the weak negative effect on the situation-related pro-immigrant attitude. Their effects (the positive effect of narcissism and negative effect of sadism) are also mediated both by the Binding and Individualizing moral foundations. The effects of Machiavellianism (positive) and psychopathy (negative) are fully mediated by the Binding, i.e., Individualizing moral concerns, respectively.

\section{Discussion}

The ongoing immigrant crisis in Europe is a kind of litmus test through which current policies and reactions from both the European states and their citizens as individuals are reflected. Solidarity and assistance on the one hand, and advocating restrictive policies, aggressive behaviour towards immigrants and the rise of the extreme right-wing and even Neo-Nazi political parties with the strong anti-immigrant platform in Europe on the other, impose the need to look at the attitudes towards the immigrant issue from a human morality perspective.

Recent theoretical and empirical accounts have suggested that both the Dark Tetrad traits and Moral Foundations, as dispositions towards morallyrelevant human behaviour, should be important for the understanding of attitudes towards immigrants. To answer this question, several hypotheses were set in this research. Firstly, both the dark personality traits and moral foundations could be significantly (negatively, except the Individualizing moral concerns) associated with the prosocial attitudes towards immigrants. Secondly, dark personality traits, especially more malicious traits like psychopathy and sadism, could be more important than moral beliefs in explanation of a situation-related, threat-provoked attitude towards immigrants than the general attitude. And, finally, moral concerns could be mediators of the relations between the dark traits and both the general and specific attitudes towards immigrants. All hypotheses were confirmed.

\section{(Im)moral roots of attitudes towards immigrants and their inter-relations}

According to the results of this study, both the Dark Tetrad traits and Moral Foundations as dispositions towards morally-relevant human behaviour are important for the understanding of attitudes towards immigrants. More specifically, the general prosocial attitude towards immigrants was explained mainly by moral foundations (the expected positive contribution of Harm/ Care and negative contributions of Authority/Respect and Purity/Sanctity), with the marginal negative effect of Machiavellianism. The situation-related 
attitude was explained both by moral foundations and the dark traits. The expected positive effect of Harm/Care was detected, as well as the negative effect of Purity/Sanctity. Also, expected significant effects of "the darkest" traits, primarily sadism, were registered.

These findings are in line with the results of previous studies (Anderson \& Cheers, 2018; Hadarics \& Kende, 2017, 2018; Hodson et al., 2009; Koleva et al., 2012) and our hypothesis that both the Dark Tetrad traits and Moral Foundations have an important contribution (negative, except the Individualizing Moral Foundations) in the explanation of prosocial attitudes towards immigrants. Consequently, these findings supported the starting point of this study that attitudes towards immigrants must be considered from the perspective of human morality (see. e.g., López-Rodríguez \& Zagefka, 2015). They are additionally important having in mind the rising of the right-wing, Neo-Nazi political movements in Europe, which refer to the morality of their attitudes about the need for the defence of their own culture, economy and the general existence of their state and ingroup from the threat posed by immigrants (Rydgren, 2017; Schmuck, \& Matthes, 2015; Wirz et al., 2018). It is also important to note that both the Dark Tetrad traits (Jones, 2013) and Binding Moral Foundations (Harnish, Bridges, \& Gump, 2017; Mather \& Jefferson, 2016) are positively associated with these conservative and right-wing, socially dominant political orientations, which "have played a prominent role in some of the darkest moments of human history" (Altemeyer, 1998; Kugler et al., 2014), and whose "morality" is, consequently, very questionable.

In this context, it is important to mention the integrative threat theory (Stephan et al., 1998) that has served as the basis for our hypothesis that when we provoke the feeling of being threatened by the immigrants, deeper and more malicious dispositions towards (im)moral behaviour will be activated. The results of our study have shown that the dark personality traits, as more fundamental moral dispositions, have a more prominent role than Moral Foundations in the prediction of the specific attitude towards immigrants presented as a situation-related, threat-provoked stimulus than in the prediction of the general attitude towards immigrants presented in a de-contextualized setting. Additionally, the threat-provoked stimuli activated more malicious dark traits - psychopathy and, more importantly, sadism. Contrary to the general attitude towards immigrants which is predicted by Machiavellianism, and whose effect is lost by the inclusion of Moral Foundations in the regression equation, the effect of sadism remains stable when the Moral Foundations are included in the model. Both of these findings are congruent with the existing research (e.g., Stephan, et al., 2005) and provide support for our integrative threattheory-based hypothesis. 
When considering the contribution of each of the Dark Tetrad traits in the explanation of both the above-mentioned types of pro-immigrant attitudes, several interesting conclusions can be made. First, we have found that Machiavellianism is most stably associated with both types of pro-immigrant attitudes, while psychopathy and sadism are related only to the situationrelated attitude towards immigrants. Narcissism has no significant effect on the prediction of these attitudes. These findings are in line with the previous studies of the relations between the dark traits and attitudes towards immigrants (Anderson \& Cheers, 2018; Hodson et al., 2009). They can be understood if we remember that both types of (negative) attitudes towards immigrants and the dark traits, especially Machiavellianism, are associated with different forms of conservatism and right-wing authoritarianism (Duspara \& Greitemeyer, 2017; Međedović \& Petrović, 2015a), which have been previously proposed as potential mediators of the relations between the dark traits and attitudes towards immigrants (Međedović \& Bulut, 2017). However, besides Machiavellianism, psychopathy is another trait which has shown stable relations with the attitudes towards immigrants (Anderson \& Cheers, 2018; Međedović \& Bulut, 2017). Although we could have expected significant effects of psychopathy, they were registered only at the level of zero-order correlations with the situation-related attitude towards immigrants, but they did not contribute to regression models. Sadism takes the lead role when compared to psychopathy. These findings suggest that people who are cynical and prone to manipulations would be more likely to express a negative attitude towards immigrants even if they are not exposed to threats. But, when an outgroup threat is perceived as a more prominent one, negative attitudes towards immigrants will be expressed by the people who are ready to hurt others. These findings and their interpretation become clearer when considering violent acts of domiciles against immigrants that have been committed in places without asylum centres, with the reduced possibility of contact with immigrants and with prevailing negative stereotypes (Denda, 2014).

Moral concerns contributions to understanding the attitudes towards immigrants could also be considered. As can be seen, both the Individualizing foundations (positively) and Binding foundations (negatively) contributed to the explanation of the prosocial attitudes towards immigrants. When we have in mind the Individualizing foundations, Harm/Care is a significant predictor of the general pro-immigrant attitude, while Fairness/Reciprocity has a prominent role in the prediction of the situation-related attitude towards immigrants. Similarly, as in the work of Koleva and her colleagues (Koleva et al., 2012), these findings suggest that, generally, prosocial attitudes towards immigrants are based on the compassion for the poor, but that pro-immigrant attitudes under the threat-provoked conditions are based on the sense of equal rights for all people. When the Binding foundations are considered, following the Moral Foundations Theory (Graham et al., 2011, 2013), it could 
be expected that Ingroup/Loyalty, as a foundation responsible for practice loyalty towards one's ingroup, would be an important predictor primarily of the situation-related attitude towards immigrants, which should facilitate the feeling of outgroup threat, but this is not the case. Our findings have shown that Purity/Sanctity, followed by Authority/Respect, are significant predictors of the anti-immigrant attitude. It means that anti-immigrant attitudes, especially the general ones, are rooted in the domiciles' need for respecting tradition and order (Authority/Respect), and, more importantly, in their fear that immigrants are dangerous and polluting foreign elements (Purity/Sanctity; see also Koleva et al., 2012). Generally, these findings are opposed to the Moral Foundations Theory (Graham et al., 2011, 2013), but consistent with the existing empirical data (Koleva et al., 2012; Kugler et al., 2014; Hadarics \& Kende, 2017, 2018).

\section{Moral Foundations mediate the link between the Dark Tetrad traits and attitudes towards immigrants}

Previous studies have shown that different moral concerns mediate the effects of personality traits on prejudices (Sibley et al., 2010), moral judgments (Djeriouat \& Trémolière, 2014), and even on the perceived threat of immigration (Hadarics \& Kende, 2017). Međedović and Bulut (2017) also suggested that some ideological dispositions could mediate the relations between the Dark Tetrad traits and their socially relevant correlates. Following these, it seemed reasonable to assume that Moral Foundations will mediate the relations between the dark traits and both the general and specific attitudes towards immigrants. The most interesting result of mediation analysis is that all four Dark Tetrad traits have significant pathways towards pro-immigrant attitudes, but also that Moral foundations have a significant mediation role in their relationships.

In this study, we have found that sadism and, more weakly, narcissism, have both direct and indirect pathways towards the specific and general attitudes towards immigrants, respectively. These findings are partially consistent with the regression analysis results from this study and have supported our assumptions that sadism has a more prominent role in a threat-provoked situation. However, in the previous analysis, we did not detect any effects of narcissism; in the model that was set, narcissism has a weak but significant positive effect primarily on the general attitude towards immigrants. This result is opposed to previous empirical evidence which has shown positive effects of narcissism on negative attitudes towards immigrants (Anderson \& Cheers, 2018; Hodson et al., 2009; Međedović \& Bulut, 2017). It can still be interpreted, especially if we have in mind that education also has a positive effect in the prediction of the general pro-immigrant attitude. If we try to summarize our findings, we could say that higher-educated 
narcissistic people will express a pro-immigrant attitude only en général, when immigrants are not perceived as any sort of threat. But, if they also have elevated conservative, Binding moral foundations, they will express negative attitudes, regardless of the presence of an outgroup threat. This finding is also in line with the research which has shown that narcissism is slightly different from the other Dark Tetrad traits (see, e.g., Petrović \& Međedović, 2016).

Different from these two, the effects of both Machiavellianism and psychopathy on the attitudes towards immigrants were fully mediated by moral concerns. The negative effect of Machiavellianism on the attitudes towards immigrants is facilitated by the Binding foundations, which fully corresponds to the assumption that conservative ideological orientation moderates the relationship between personality and attitudes. In this context, it should be emphasized that both Machiavellianism (Duspara \& Greitemeyer, 2017) and Binding concerns (Graham et al., 2011) are related to conservative ideology, as well as that prejudices towards immigrants are rooted in the conservative ideology (Duckitt, Bizumic, Krauss, \& Heled, 2010; Petrović, 2017).

On the other hand, the effects of psychopathy are fully mediated by the Individualizing foundations. Having in mind that psychopathy is defined through callousness, impulsivity, lack of care about others and lack of remorse, and that it represents one of the more malignant members of the Dark Tetrad, its negative relation with the Individualizing moral foundations is not surprising (see, e.g., Međedović \& Petrović, 2016). However, the lack of direct pathways towards the attitudes towards immigrants is a little surprising, having in mind the previous findings (e.g., Anderson \& Cheers, 2018). It could be reasonably assumed that its effects on attitudes towards immigrants are suppressed by sadism, having in mind a high correlation between psychopathy and sadism. The mediating role of the Individualizing foundations suggested that they can slightly alleviate the negative effect of psychopathy on pro-immigrant attitudes.

\section{Limitations and conclusions}

Although the findings of this research are important and implicative, its main limitation is the operationalization of the attitudes towards immigrants - both of them were measured by one item, with a relatively limited range of respondents' responses. Therefore, it would be necessary to measure the attitudes towards immigrants more adequately, by an instrument with a larger number of items, which would enable a more reliable assessment of the attitude towards immigrants. Additionally, the way these attitudes were measured indicates the possibility of facilitating the immigrant threat in general, but not specifically, in terms of a realistic or symbolic threat. The 
research generally shows that people react differently depending on the type of threat which is concerned (see, e.g., Međedović \& Bulut, 2017; Schmuck \& Matthes, 2015). Finally, it would be probably important to combine a correlational and experimental approach in order to directly induce a sense of an economic or cultural threat rather than to access these important variables in an indirect way. Some of the future studies should take this into account.

In conclusion, when considering the contributions of the Dark Tetrad and Moral Foundations to understanding the attitudes towards immigrants, it might be said that under the perception of concrete threats from the "others" (immigrants with different skin colour, nationality, religion, from other countries) towards someone's ingroup, the formal boundaries of morality were weakened (the negative effect of Purity/Sanctity) and the most malicious personality traits were expressed (sadism). Thereby, the conservative, Binding foundations amplified, while the Individualizing ones buffered the negative effects of the Dark Tetrad traits on the prosocial attitudes towards immigrants. These two more important findings have both practical and theoretical implications. The practical implication is that the results of this study additionally indicate the risk of the rise of the extreme conservative, rightwing and even Neo-Nazi political parties, with a strong binding-promoted and anti-immigrant platform in Europe. The theoretical implication is that the results of the study, as well as their main practical implications, suggest that the Moral Foundation Theory needs to be significantly revised. The findings of this study suggested that the Binding foundations might be what different people think that morality is, but it does not mean that this is morality per se.

\section{References}

Altemeyer, B. (1998). The other "Authoritarian Personality”. In M. Zanna (Ed.), Advances in Experimental Social Psychology. (pp. 47-92). San Diego: Academic Press. doi:10.1016/s0065-2601(08)60382-2

Anderson, J., \& Cheers, C. (2017). Does the Dark Triad predict prejudice? The role of Machiavellianism, psychopathy, and narcissism in explaining negativity toward asylum aeekers. Australian Psychologist, 53(3), 271-281. doi:10.1111/ap.12283

Buckels, E. E., Jones, D. N., \& Paulhus, D. L. (2013). Behavioral confirmation of everyday sadism. Psychological Science, 24(11), 2201-2209. doi:10.1177/0956797613490749

Ceobanu, A. M., \& Escandell, X. (2010). Comparative analyses of public attitudes toward immigrants and immigration using multinational survey data: A review of theories and research. Annual Review of Sociology, 36(1), 309-328. doi:10.1146/annurev.soc.012809.102651

Chabrol, H., Van, L. N., Rodgers, R., \& Séjourné, N. (2009). Contributions of psychopathic, narcissistic, Machiavellian, and sadistic personality traits to juvenile delinquency. Personality and Individual Differences, 47(7), 734-739. doi:10.1016/j. paid.2009.06.020 
Denda, S. (2014). Asylum seekers in Serbia: Between law and reality. Demography, 11, 147-172.

Dinić, B. M., Petrović, B., \& Jonason, P. K. (2018). Serbian adaptations of the Dark Triad Dirty Dozen (DTDD) and Short Dark Triad (SD3). Personality and Individual Differences, 134, 321-328. doi:10.1016/j.paid.2018.06.018

Dinić, B. M., Bulut, T., Petrović, B., \& Wertag, A. (under review). A test of three sadism measures: Short Sadistic Impulse Scale, Varieties of Sadistic Tendencies, and Assessment of Sadistic Personality. Manuscript under review.

Djeriouat, H., \& Trémolière, B. (2014). The Dark Triad of personality and utilitarian moral judgment: The mediating role of Honesty/Humility and Harm/Care. Personality and Individual Differences, 67, 11-16. doi:10.1016/j.paid.2013.12.026

Duckitt, J., Bizumic, B., Krauss, S. W., \& Heled, E. (2010). A tripartite approach to right-wing authoritarianism: The Authoritarianism-Conservatism-Traditionalism model. Political Psychology, 31(5), 685-715. doi:10.1111/j.14679221.2010.00781.x

Duspara, B., \& Greitemeyer, T. (2017). The impact of dark tetrad traits on political orientation and extremism: an analysis in the course of a presidential election. Heliyon, 3(10), doi:10.1016/j.heliyon.2017.e00425

Graham, J., Haidt, J., Koleva, S., Motyl, M., Iyer, R., Wojcik, S. P., \& Ditto, P. H. (2013). Moral Foundations Theory: The pragmatic validity of moral pluralism. Advances in Experimental Social Psychology, 47, 55-130. doi:10.1016/b9780-12-407236-7.00002-4

Graham, J., Nosek, B. A., Haidt, J., Iyer, R., Koleva, S., \& Ditto, P. H. (2011). Mapping the moral domain. Journal of Personality and Social Psychology, 101(2), 366-385. doi: $10.1037 / \mathrm{a} 0021847$

Hadarics, M., \& Kende, A. (2017). A closer look at intergroup threat within the dual process model framework: The mediating role of moral foundations. Psychological Thought, 10(1), 167-177. doi:10.5964/psyct.v10i1.210

Hadarics, M., \& Kende, A. (2018). Moral foundations of positive and negative intergroup behavior: Moral exclusion fills the gap. International Journal of Intercultural Relations, 64, 67-76. doi:10.1016/j.ijintrel.2018.03.006

Hainmueller, J., \& Hopkins, D. J. (2014). Public attitudes toward immigration. Annual Review of Political Science, 17(1), 225-249. doi:10.1146/annurev-polisci-102512-194818

Harnish, R. J., Bridges, K. R., \& Gump, J. T. (2018). Predicting economic, social, and foreign policy conservatism: the role of Right-Wing Authoritarianism, Social Dominance Orientation, Moral Foundations orientation, and religious fundamentalism. Current Psychology, 37(3), 668-679. doi:10.1007/s12144-016-9552-x

Hodson, G., Hogg, S. M., \&MacInnis, C. C. (2009). The role of "dark personalities" (narcissism, Machiavellianism, psychopathy), Big Five personality factors, and ideology in explaining prejudice. Journal of Research in Personality, 43(4), 686690. doi:10.1016/j.jrp.2009.02.005

Jonason, P. K. (2015). How "dark" personality traits and perceptions come together to predict racism in Australia. Personality and Individual Differences, 72, 47-51. doi:10.1016/j.paid.2014.08.030 
Jones, D. N. (2013). Psychopathy and machiavellianism predict differences in racially motivated attitudes and their affiliations. Journal of Applied Social Psycho$\log$, 43, doi:10.1111/jasp.12035

Jones, D. N., \& Paulhus, D. L. (2014). Introducing the Short Dark Triad (SD3): A brief measure of dark personalities. Journal of Research in Personality, 21(1), 2841. doi:10.1177/1073191113514105

Karandikar, S., Kapoor, H., Fernandes, S., \& Jonason, P. K. (2018). Predicting moral decision-making with dark personalities and moral values. Personality and Individual Differences, 140, 70-75. doi:10.1016/j.paid.2018.03.048

Koleva, S. P., Graham, J., Iyer, R., Ditto, P. H., \& Haidt, J. (2012). Tracing the threads: How five moral concerns (especially Purity) help explain culture war attitudes. Journal of Research in Personality, 46(2), 184-194. doi:10.1016/j. jrp.2012.01.006

Kugler, M., Jost, J. T., \& Noorbaloochi, S. (2014). Another look at Moral Foundations Theory: Do authoritarianism and Social Dominance Orientation explain liberal-conservative differences in "moral" intuitions. Social Justice Research, 27(4), 413-431. doi:10.1007/s11211-014-0223-5

López-Rodríguez, L., \& Zagefka, H. (2015). The effects of stereotype content on acculturation preferences and prosocial tendencies: The prominent role of morality. International Journal of Intercultural Relations, 45, 36-46. doi:10.1016/j. ijintrel.2014.12.006

Mather, R. D., \& Jefferson, K. W. (2016). The authoritarian voter? The psychology and values of Donald Trump and Bernie Sanders support. Journal of Scientific Psychology, 1-8.

Međedović, J., \& Bulut, T. (2017). Expanding the nomogical network of Dark Tetrad: The case of cynicism, aggressive humor and attitudes towards immigrants. Zbornik Instituta za kriminološka i sociološka istraživanja, 36, 7-19.

Međedović, J., \& Petrović, B. (2015). The Dark Tetrad: Structural properties and location in the personality space. Journal of Individual Differences, 36(4), 228-236. doi:10.1027/1614-0001/a000179

Međedović, J., \& Petrović, B. (2015a). Social attitudes as mediators of the link between personality and militant extremists thinking pattern. Zbornik Instituta za Kriminološka i Sociološka Istraživanja, 34, 7-25.

Međedović, J., \& Petrovic, B. (2016). Can there be an immoral morality? Dark personality traits as predictors of moral foundations. Psihologija, 49(2), 185-197. doi:10.2298/psi1602185m

Meltzer, C. E., Eberl, J. M., Theorin, N., Lind, F., Schemer, C., Boomgaarden, H. G., \& et al., (2018). Perceptions of the Impact of Immigration and Attitudes Towards Free Movement Within the EU: A Cross-National Study. Mainz - Vienna - Gothenburg. Project Reminder.

Milojev, P., Osborne, D., Greaves, L. M., Bulbulia, J., Wilson, M. S., Davies, C. L., . . Sibley, C.G. (2014). Right-Wing Authoritarianism and Social Dominance Orientation predict different moral signatures. Social Justice Research, 27(2), 149-174. doi:10.1007/s11211-014-0213-7 
Nicol, A. A. M., \& Rounding, K. (2018). Can ethical ideologies predict prejudice. Ethics \& Behavior, 28(8), 662-679. doi:10.1080/10508422.2017.1416292

O'Meara, A., Davies, J., \& Hammond, S. (2011). The psychometric properties and utility of the Short Sadistic Impulse Scale (SSIS). Psychological Assessment, 23(2), 523-531. doi:10.1037/a0022400

Paulhus, D. L., \& Williams, K. M. (2002). The Dark Triad of personality: Narcissism, Machiavellianism, and psychopathy. Journal of Research in Personality, 36(6), 556-563. doi:10.1016/s0092-6566(02)00505-6

Petrović, B. (2016). Personal and contextual determinants of attitudes towards immigrants. Psihološka istraživanja, 19(2), 223-240. doi:10.5937/psistra1602223p

Petrović, B. (2017). Contextual and attitudinal determinants of attitudes towards immigrants: Security implications. Zbornik Instituta za Kriminološka i Sociološka Istraživanja, 36, 7-21.

Petrović, B., \& Međedović, J. (2016). Personality and behavioural characteristics of dark and light narcissism. Zbornik Instituta za Kriminološka i Sociološka Istraživanja, 35, 7-33.

Rydgren, J. (2017). Radical right-wing parties in Europe. Journal of Language and Politics, 16(4), 485-496. doi:10.1075/jlp.17024.ryd

Schmuck, D., \& Matthes, J. (2015). How anti-immigrant rght-wing populist advertisements affect young voters: Symbolic threats, economic threats and the moderating role of education. Journal of Ethnic and Migration Studies, 41(10), 15771599. doi:10.1080/1369183x.2014.981513

Sibley, C. G., Harding, J. F., Perry, R., Asbrock, F., \& Duckitt, J. (2010). Personality and prejudice: Extension to the HEXACO personality model. European Journal of Personality, 24(6), 515-534. doi:10.1002/per.750

Stephan, W. G., Lausanne, R. C., Esses, V. M., White, S. C., \& Martin, T. (2005). The effects of feeling threatened on attitudes toward immigrants. International Journal of Intercultural Relations, 29(1), 1-19. doi:10.1016/j.ijintrel.2005.04.011

Stephan, W. G., Ybarra, O., Martnez, C. M., Schwarzwald, J., \& Tur-Kaspa, M. (1998). Prejudice toward immigrants to Spain and Israel: An integrated threat theory analysis. Journal of Cross-Cultural Psychology, 29(4), 559-576. doi:10.1177/0022022198294004

Valentino, N. A., Soroka, S. N., Iyengar, S., Aalberg, T., Duch, R., Fraile, M., ... Kobayashi, T. (2017). Economic and cultural drivers of immigrant support worldwide. British Journal of Political Science, 1-26. doi:10.1017/s000712341700031x

Veebel, V., \& Markus, R. (2015). Europe's refugee crisis in 2015 and security threats from the Baltic perspective. Journal of Politics and Law, 8(4), doi:10.5539/jpl. v8n4p254

Wirz, D. S., Wettstein, M., Schulz, A., Müller, P., Schemer, C., Ernst, N., . . . Wirth, W. (2018). The effects of right-wing populist communication on emotions and cognitions toward immigrants. The International Journal of Press/Politics, 23(4), 496-516. doi:10.1177/1940161218788956 


\title{
(A)moralni aspekti stavova prema imigrantima: Uloga Mračne Tetrade i Moralnih Osnova
}

\author{
Boban Petrović \\ Institut za kriminološka i sociološka istraživanja, Beograd
}

Imigracija i izbeglička kriza predstavljaju jedan od glavnih problema sa kojima se trenutno suočavaju mnoge evropske zemlje, uključujući i one u tranziciji kao što je Srbija. Reakcije na imigrante i izbeglice sa Bliskog istoka i severne Afrike su oštro podeljene i upućuju na pitanje moralnih aspekata stavova prema izbeglicama. U poslednje vreme, ljudska (a)moralnost je počela da se istražuje pomoću koncepata Mračne Tetrade i Moralnih Osnova. Cilj ovog istraživanja je da ispita ulogu Mračne Tetrade i Moralnih Osnova u razumevanju opštih i specifičnih, situaciono određenih, prosocijalnih stavova prema imigrantima. Rezultati studije (N=629 ispitanika iz Srbije) pokazali su da Povreda/Briga i Poštenje/Reciprocitet (Individualizirajuće Moralne Osnove) negativno koreliraju sa crtama Mračne Tetrade. Sa druge strane, Unutargrupna/Lojalnost, Autoritet/Poštovanje i Čistota/ Svetost (Vezujuće Moralne Osnove) pozitivno koreliraju sa ovim crtama. Opšti stav prema imigrantima je objašnjen pre svega pomoću Moralnih Osnova: pozitivni efekat Povrede/Brige i negativni efekti Autoritet/Poštovanja i Čistote/Svetosti su detektovani, zajedno sa marginalnim efektima Makijavelizma. Specifični stav prema imigrantima je objašnjen i pomoću Mračne Tetrade i pomoću Moralnih Osnova. Detektovani su očekivani pozitivni efekti Poštenja/Reciprociteta i negativni efekti sadizma i Čistote/Svetosti. Takođe, pokazano je da Moralne osnove posreduju u odnosima između Mračne Tetrade i stavova prema imigrantima. Jedino narcizam i sadizam su imali direktne efekte na stavove prema imigrantima. Vezujuće Osnove amplifikuju dok Individualizirajuće osnove umanjuju negativne efekte Mračne Tetrade kako na generalne tako i na specifične stavove prema imigrantima. Ovi nalazi sugerišu da kad ljudi precipiraju "druge" kao pretnju grupi kojoj pripadaju, formalne granice moralnosti slabe što dovodi do ispoljavanja čak i najmalicioznijih crta ličnosti.

Ključne reči: moralnost, imigranti, stavovi, Mračna Tetrada, Moralne Osnove 


\section{Appendix: \\ Latent structure of the Moral Foundations}

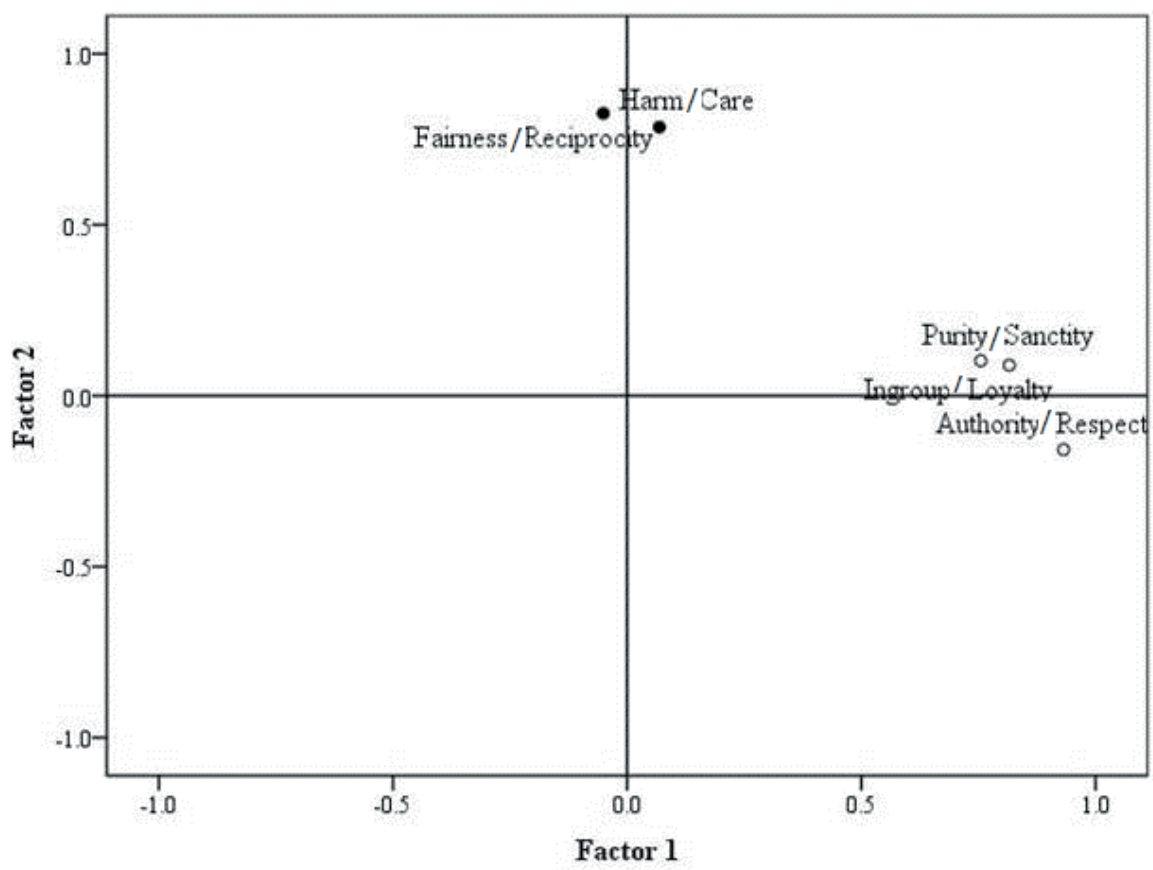

Figure A1. Latent structure of the Moral Foundations: rotated components in a two-dimensional space. 